\title{
MENINGKATKAN HASIL BELAJAR SISWA PADA PELAJARAN ILMU PENGETAHUAN ALAM DI KELAS VII-3 MELALUI STRATEGI PEMBELAJARAN PENINGKATAN KEMAMPUAN BERFIKIR DI SMP NEGERI 29 MEDAN PADA TAHUN PELAJARAN 2017/2018
}

\author{
Sauli Fairida Siregar, SPd \\ Guru SMP Negeri 29 Medan \\ saulifaridasiregar@yahoo.com
}

\begin{abstract}
Abstrak
Tujuan penelitian ini adalah untuk: Meningkatkan hasil belajar siswa pada Pelajaran Ilmu Pengetahuan Alam di Kelas VII-3 melalui strategi pembelajaran peningkatan kemampuan berpikir di SMP Negeri 29 Medan padaTahun Pelajaran 2017/2018. Metode penelitian yang digunakan dalam penelitian ini adalah Metode Penelitian Tindakan Kelas dengan menggunakan 2 siklus. Subjek penelitian ini adalah siswa Kelas VII-3 SMP Negeri 29 Medan sebanyak 36 orang. Teknik pengumpulan data yang digunakan untuk memperoleh data adalah menggunakan test, angket dan observasi. Rentang nilai untuk tes adalah 1-100. Teknik analisa data yang digunakan adalah menggunakan teknik penghitungan nilai rata-rata hasil belajar siswa, persentase nilai ketuntasan siswa dan persentase nilai ketidaktuntasan siswa. Hasil Penelitian ini menunjukkan terdapat peningkatan hasil belajar dengan menerapkan strategi pembelajaran peningkatan kemampuan berfikir dengan hasil sebagai berikut: (1) terdapat peningkatan rata-rata hasil belajar siswa, dimana pada tes awal rata-rata hasil belajar siswa adalah 47,78, pada siklus I meningkatkan menjadi 65,0 kemudian pada siklus II meningkat lagi menjadi 76,39 , terdapat peningkatan jumlah siswa yang tuntas, dimana pada tes awal jumlah siswa yang tuntas hanya $0 \%$, meningkat menjadi $44,44 \%$ pada siklus I kemudian meningkat lagi menjadi $88,88 \%$ pada siklus II, terdapat penurunan jumlah siswa yang tidak tuntas, dimana pada tes awal jumlah siswa yang tidak tuntas mencapai $100 \%$, pada siklus I menjadi $55,56 \%$ kemudian pada siklus II menurun lagi menjadi $11,12 \%$ dengan kata lain hanya 4 orang siswa saja yang memperoleh nilai di bawah 70 dan selebihnya (32) orang siswa memperoleh nilai di atas 70 .
\end{abstract}

Kata Kunci : Hasil belajar, Strategi Pembelajaran, Strategi Pembelajaran

Peningkatan Kemampuan Berfikir.

\begin{abstract}
The aim of this study is to improve of student achievement on Science at class VII-3 through the increasing of the ability of thinking strategy at SMP Negeri 29 Medan in 2017/2018 academic year. The method of this study is classroom action
\end{abstract}


research by using two cycles. The subject of this study is the students of VII-3 grade SMP Negeri 29 Medan. There are 36 students. The techniques to collecting data are test, questioner and observation. The range score for test is 1-100. The technique of analysing data is to to count the average of percentage of the students who pass the standard minimal score and yet. The resullt of the study are: (1) There are the increasing average of students achivement, where pre-test is 47,78 , at first cycle is increasing to 65 and the second cycle is increasing to 76,39. There are the increasing of the amount of students who pass the test, at the pre-test the students who pass the test is $0 \%$, and the first cycle it tobe $44,44 \%$ and the second cycle is to be $88,88 \%$. There are the decreasing of the students who fail the test. At pre-test there $100 \%$ students are fail and at first cycle is decreasing to be $55,56 \%$ and at second cycle is tobe $11,12 \%$. On the other hand There are only 4 students who get the score under 70 and 32 students get score more than 70 .

Key words : Students achievement, Learning Strategy, the increasing of the ability of thinking strategy

\section{PENDAHULUAN}

\subsection{Latar Belakang Masalah}

Guru IPA belum menerapkan strategi pembelajaran yang dapat membuat siswa aktif dalam proses pembelajaran dan belum menerapkan pembelajaran yang berpusat pada siswa. Guru harus menciptakan kondisi belajar yang aktif dan kreatif. Kegiatan pembelajaran harus menantang, mendorong eksplorasi memberi pengalaman belajar, dan mengembangkan kreatifitas siswa.

Berdasarkan kenyataan yang terjadi pada kegiatan proses pembelajaran Ilmu Pengetahuan Alam pada kelas VII-3 SMP Negeri 29 Medan, disimpulkan bahwa kualitas pembelajaran akan meningkat jika guru mampu menciptakan kondisi belajar yang aktif, kreatif, dan mengefektifkan komunikasi interaksi guru dan siswa menggunakan metode pembelajaran yang tepat.
Berdasarkan fakta-fakta di atas, maka dilakukan usaha untuk meningkatkan minat siswa dan hasil belajar siswa melalui cara merubah strategi pembelajaran yang diterapkan di dalam kelas yang selama ini menggunakan strategi pembelajaran konvensional menjadi strategi pembelajaran yang berpusat pada siswa. Oleh sebab itu dibuat penelitian yang berjudul "Meningkatkan Hasil Belajar Siswa Pada Pelajaran Ilmu Pengetahuan Alam di Kelas VII-3 melalui Strategi Pembelajaran Peningkatan Kemampuan Berfikir di SMP Negeri 29 Medan pada Tahun Pelajaran $2017 / 2018$.

\subsection{Perumusan Masalah}

Apakah strategi pembelajaran peningkatan kemampuan berfikir dapat meningkatkan hasil belajar siswa pada Pelajaran Ilmu Pengetahuan Alam Kelas VII-3 SMP Negeri 29 Medan pada Tahun Pelajaran 2017/2018?. 


\subsection{Tujuan Penelitian}

Untuk meningkatkan hasil belajar siswa pada Pelajaran Ilmu Pengetahuan Alam di Kelas VII-3 di SMP Negeri 29 Medan melalui Strategi Pembelajaran peningkatan kemampuan berfikir pada Tahun pelajaran 2017/2018.

\section{METODE PENELITIAN}

Penelitian ini dilaksanakan pada SMP Negeri 29 Medan Jalan Benteng hulu Kecamatan Medan Tembung Kota Medan Provinsi Sumatera Utara. Adapun waktu penelitian ini dilaksanakan selama 6 bulan, yakni mulai dari bulan Juli 2017 sampai Desember 2017.

Subjek pada penelitian ini adalah siswa Kelas VII-3 semester I (ganjil) Tahun Pelajaran 2017/2018 di SMP Negeri 29 Medan dengan jumlah siswa sebanyak 36 orang.

Metode yang digunakan dalam penelitian ini adalah menggunakan metode penelitian tindakan kelas dengan menggunakan 2 siklus, dimana setiap siklus terdiri dari: perencanaan, pelaksanaan, evaluasi dan refleksi ( Arikunto, 2010: 6)

Teknik pengumpulan data yang digunakan dalam penelitian ini adalah menggunakan: (1) angket, (2) tes dan (3) observasi. Angket digunakan untuk mengumpulkan data tentang minat siswa, kemudian tes digunakan untuk menjaring data siswa,

Teknik analisa data yang digunakan adalah menggunakan teknik penghitungan nilai rata rata hasil belajar siswa, persentase nilai ketuntasan siswa dan persentase nilai ketidaktuntasan siswa. Data di analisa dengan metode penilaian yaitu: data yang diperoleh dilakukan evaluasi berdasarkan hasil belajar siswa. Evaluasi hasil belajar siswa diberi rentang nilai dari $0-100$ untuk menentukan tingkatan prestasi belajar siswa kemudian untuk angket minat siswa di analisa berdasarkan jumlah jawaban siswa yang menjawab "ya" atau "tidak". Apabila $80 \%$ dari indikator minat siswa dijawab "Ya" maka dinyatakan siswa memiliki minat yang tinggi.

Dalam penelitian tindakan kelas (PTK) ini akan dilihat indikator kinerjanya selain siswa, guru merupakan fasilitator yang sangat berpengaruh terhadap kinerja siswa. Adapun indikator kinerja dalam penelitian ini adalah jika $80 \%$ siswa memperoleh nilai sama dengan 70 atau lebih dan $80 \%$ siswa aktif dalam kegiatan belajar mengajar, maka penelitian sudah jenuh sehingga tak perlu dilanjutkan ke siklus berikutnya.

\section{HASIL PENELITIAN DAN PEMBAHASAN}

\subsection{Pembahasan Siklus I}

Berdasarkan perolehan data, terjadi peningkatan hasil belajar antara tes awal dengan siklus I yakni: (1) pada tes awal rata-rata hasil belajar adalah 47,78 sedangkan pada siklus I menjadi 65,0, (2) pada tes awal jumlah ketuntasan siswa adalah $0 \%$ sedangkan pada siklus I menjadi $44,44 \%$ dan (3) jumlah siswa yang belum tuntas pada tes awal adalah $100 \%$ sedangkan pada siklus I jumlah siswa yang belum tuntas berkurang menjadi 55,56\%. Oleh karena jumlah siswa yang tuntas belum mencapai $80 \%$ (masih 
44,44\%) maka perlu dilanjutkan ke siklus berikutnya yakni siklus II.

\subsection{Pembahasan Siklus II}

Berdasarkan hasil belajar pada siklus II dengan nilai rata-rata 76,39 , jumlah siswa yang memperoleh nilai 70 mencapai 88,88\% (32 siswa) dan jumlah siswa yang memperoleh nilai 70 ke bawah hanya $11,12 \%$. ( hanya 4 siswa) Ini berarti penelitian telah berhasil karena indikator kinerja yang ditetapkan adalah $80 \%$ siswa memperoleh nilai 70 sedangkan pada siklus II ini siswa yang memperoleh nilai 70 mencapai $88,88 \%$. Ini berarti penelitian tidak perlu dilanjut ke siklus berikutnya.

Berdasarkan data hasil belajar siswa, penerapan SPPKB dapat meningkatkan hasil belajar siswa. Hal ini dapat dilihat dari hasil belajar siswa pada siklus I dan siklus II berikut:

1. Terdapat peningkatan rata-rata hasil belajar siswa, dimana pada tes awal rata-rata hasil belajar siswa adalah 47,78, pada siklus I meningkatkan menjadi 65,0 kemudian pada siklus II meningkat lagi menjadi 76,39.

2. Terdapat peningkatan jumlah siswa yang tuntas, dimana pada tes awal jumlah siswa yang tuntas hanya $0 \%$, meningkat menjadi $44,44 \%$ pada siklus I kemudian meningkat lagi menjadi $88,88 \%$ pada siklus II

3. Terdapat penurunan jumlah siswa yang tidak tuntas, dimana pada tes awal jumlah siswa yang tidak tuntas mencapai $100 \%$, pada siklus I menurun menjadi 55,56\% kemudian pada siklus II menurun lagi menjadi 11,12\% dengan kata lain hanya 4 siswa saja yang memperoleh nilai 70 ke bawah dan selebihnya (32) siswa memperoleh nilai di atas 60 . Hal tersebut di atas dapat dilihat pada diagram di bawah ini:

\section{Diagram 4.4}

Hasil Belajar, Tes Awal, Siklus I, Siklus II

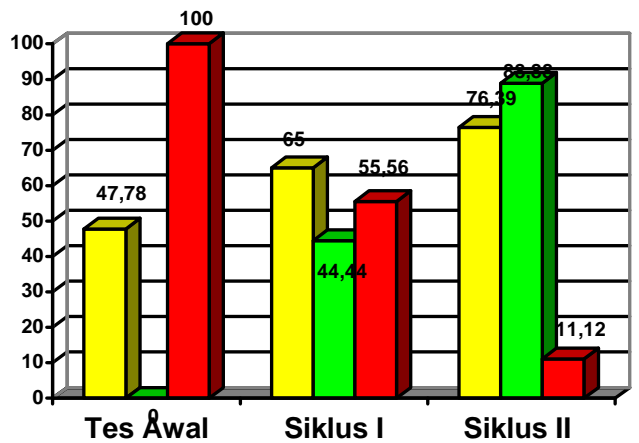

Keterangan:

Kuning $\square=$ Rata-rata
Hijau $\square=$ Tuntas
Merah $\square=$ Tidak Tuntas

\section{KESIMPULAN}

Berdasarkan hasil belajar siswa di atas, maka disimpulkan bahwa: Hasil belajar siswa yang diajar menggunakan strategi pembelajaran peningkatan kemampuan berfikir dapat meningkat, terdapat peningkatan rata-rata hasil belajar siswa, dimana pada tes awal rata-rata hasil belajar siswa adalah 47,78, pada siklus I meningkatkan menjadi 65,0 kemudian pada siklus II meningkat lagi menjadi 76,39, terdapat peningkatan jumlah siswa yang tuntas, dimana pada tes awal jumlah siswa yang tuntas hanya $0 \%$, 
meningkat menjadi $44,44 \%$ pada siklus I kemudian meningkat lagi menjadi $88,88 \%$ pada siklus II, terdapat penurunan jumlah siswa yang tidak tuntas, dimana pada tes awal jumlah siswa yang tidak tuntas mencapai $100 \%$, pada siklus I menjadi 55,56\% kemudian pada siklus II menurun lagi menjadi $11,12 \%$ dengan kata lain hanya 4 siswa saja yang memperoleh nilai di bawah 70 dan selebihnya (32) siswa memperoleh nilai 70 dan di atas 70 .

\section{DAFTAR PUSTAKA}

Arikunto, Suharsimi. 2010. Penelitian Tindakan Kelas. Jakarta: Rieneka Cipta
Dimyati \& Mudjiono.2013. Strategi Belajar Mengajar.Jakarta: Bumi Aksara.

Hamdani. 2011. Strategi Belajar Mengajar. Bandung: Pustaka Setia

Hamalik. 2011. Belajar dan Hasil Belajar. Jakarta: Rajawali

Sanjaya, Wina. 2011. Pendekatan Berorientasi Standar Proses Pendidikan. Jakarta Kharisma Putra Utama.

Sugandi, A. 2004. Teori Pembelajaran. Semarang: UPT MKK Universitas Negeri Malang. 